\title{
The Landless Voices Database: A Trajectory from Cultural Studies to Pedagogical Impact
}

\section{O Banco de Dados Eletrônico Vozes Sem-Terra: uma trajetória dos estudos culturais ao impacto pedagógico}

\author{
Else R. P. Vieira ${ }^{1}$
}

\begin{abstract}
This article initially addresses the conception of the web-enabled database Landless Voices (VIEIRA, 2003) as a contribution to Cultural Studies and, crucially, to the understanding of the relational workings of Brazil's complex and regionally diverse culture of landlessness, and to the validation of the cultural self-expression of the sem-terra/Sem Terra. Secondly, it analyzes speculative data obtained from prospective primary teachers being trained at the Federal University of Paraná, Brazil, on the contribution of the database to the pedagogical context. The main findings are that the three predominant types of impact, using Meagher's terminology (2013, p. 5) are conceptual (new knowledge), cultural (revising misconceptions) and instrumental (future development of pedagogic practices). It then moves to empirical research on social impact, understood as the contribution of academic research to non-academic users, more specifically to its presumably main beneficiaries - the Sem Terra learners themselves. The findings of these first exploratory workshops with learners in four rural schools in settlements in the states of Paraná and São Paulo, respectively in October and November 2013, are that the database broadens their educational resources and empowers a historically marginalized social segment. This article confirms, however, that impact is not a punctual activity (MEAGHER, 2013) and concludes on
\end{abstract}

DOI: $10.1590 / 0104-4060.39850$ E14 NS.

1 Queen Mary University of London. London, United Kingdom. 327 Mile End Road, 
the need for continuous interaction with learners for the pedagogic impact of academic research to be generated ${ }^{2}$.

Keywords: cultural studies; web-enabled landless voices database; social impact; pedagogical impact.

\section{RESUMO}

Este artigo aborda, inicialmente, a concepção do banco de dados eletrônico Landless Voices/Vozes Sem Terra (VIEIRA, 2003), como uma contribuição para os Estudos Culturais e, crucialmente, para a compreensão do funcionamento relacional da complexa e regionalmente diversificada cultura dos sem-terra/Sem Terra do Brasil e para a legitimização de suas autoexpressões culturais. Em segundo lugar, analisa os dados especulativos fornecidos por professores primários em treinamento na Universidade Federal do Paraná, Brasil, bem como sobre a contribuição do banco de dados para o contexto pedagógico. As principais conclusões são de que os três tipos predominantes de impacto, usando a terminologia de Meagher (2013, p. 5), são o conceitual (novo conhecimento), cultural (revisão de ideias equivocadas) e instrumental (futuro desenvolvimento de práticas pedagógicas). O artigo se volta, então, para o impacto social, entendido como a contribuição da pesquisa acadêmica para usuários não acadêmicos, mais especificamente para os seus principais beneficiários potenciais - os próprios alunos Sem Terra. Os achados das oficinas exploratórias com os alunos de quatro escolas rurais em assentamentos nos estados do Paraná e São Paulo, respectivamente em outubro e novembro de 2013, são que ele amplia seus recursos educacionais e empodera um segmento social historicamente marginalizado. O artigo confirma, todavia, que o impacto não é uma atividade pontual (MEAGHER, 2013) e conclui sobre a necessidade de uma interação contínua com os alunos para que o impacto pedagógico da pesquisa acadêmica seja gerado.

Palavras-chave: estudos culturais; banco de dados eletrônico vozes-sem-terra; impacto social; impacto pedagógico.

2 This is part of Landless Voices Impact Enhancement Project, developed by Professor Else R. P. Vieira (Principal investigator) and co-researchers: Dr. Sônia Schwendler (Federal University of Paraná, UFPR) and Professor Bernardo Mançano Fernandes (São Paulo based UNESCO’s Chair in Territorial Development and Education for the Countryside; MA in Territorial Development in Latin American and Caribbean of the São Paulo State University - UNESP, and PhD Programme in Geography, Presidente Prudente Campus), both honorary researchers at Queen Mary's Department of Iberian and Latin American Studies. This research on impact is financed by the School of Languages, Linguistics and Film (Queen Mary University of London) with the support of UFPR School of Education and of UNESP Centre for Agrarian Reform Studies, Research and Projects - NERA). 


\section{Introduction}

The web-enabled database, Landless Voices (2003), compiled by Else R. P. Vieira, as the main investigator and research director, contains $500+$ resources that project the cultural self-expression of Brazilian sem-terra/Sem Terra across several media ${ }^{3}$. When it was first launched in the House of Commons (London) and in the Via Campesina Conference (Porto Alegre, Brazil) in January 2003, peer reviews praised its merit as a research tool (analyzed in part 1 below) and, equally importantly, brought out its pedagogical potential, which this article then explores. Mention is made of the $5 *$ rating achieved in the review by Multimedia Educational Resources for Learning and Online Teaching (MERLOT), for "its excellent development of learning and teaching materials" and "superb use of media to reach a wide variety of learning styles and audiences [...] one can take a cultural, historical, political and/or scholarly approach to the topic, simply by focusing on particular resources and the various cultural themes". According to INTUTE, a service created by a network of UK Universities, providing access to the best web resources for education and research, "this exceptional archive offers the researcher and student invaluable access to the emerging culture of the landless in Brazil, encompassing a comprehensive variety of media".

As the pendulum is shifted initially to speculative research on impact, understood as the contribution of academic research to wider society, it will analyze data collected by Dr. Sônia Schwendler in May 2013 from prospective primary teachers being trained at the Federal University of Paraná (hereafter UFPR), Brazil, on the foreseeable contribution of a Cultural Studies-oriented database to the pedagogical context. It will then analyze data collected through workshops on the reception of the database in rural schools in 2013. The roles of co-researchers Schwendler and Bernardo Mançano Fernandes were crucial for liaison with rural schools in settlements and the recruitment of primary and secondary learners, respectively, in the states of Paraná (11 million+ inhabitants) and São Paulo (44 million+ inhabitants). Both strands of the research (speculative and empirical) are part of the umbrella of the International Integrated Landless

3 The different stages of the politicization of the landless identity are signalled throughout this article by the spelling shift from sem-terra to Sem Terra. Lower-case and hyphenated sem-terra connotes the condition of dispossession of those rural workers who do not have access to the land as a means of production; it is related to the confrontational stages of the struggle for land, involving the setting up of encampments in non-productive latifundia or by the sides of roads as spaces of resistance. Upper-case, non-hyphenated Sem Terra designates a political subject, the rural worker who has already received a plot of land in the settlements but who remains a participant in the Movement in solidarity with those who have not yet been granted the same benefits. 
Voices Impact Enhancement Project (see note 2). Conclusions will also be drawn on the research impact methodology so far developed by the Project.

\section{Landless Voices: Enhancing Cultural Studies through a Web- Enabled Database}

The Movement of the Landless Rural Workers of Brazil - MST - officially established in 1984, gave visibility to the escalation of the social tragedy of landlessness which still bedevils millions of rural people in Brazil, paradoxically the world's fifth-largest country. The three-year initial project ${ }^{4}$, which gave rise to today's database Landless Voices, begun in 2000, when the debates on landlessness in Brazil were at the forefront on the occasion of the commemoration of 500 years of its discovery in 1500 by Portugal. The aims and objectives of the project were the first-hand collection, organization and dissemination of the sem-terra's/Sem Terra's various forms of self-expression, in order to provide the basis for the expansion of research and scholarship on the culture emerging from this major Social Movement. It was intended to be a landlessness-specific contribution to Cultural Studies and to assist in the creation of a public space for the sem-terra/Sem Terra social segment to express their subjectivities, their sense of dispossession, struggles for land, traumas, and hopes, as well as providing a political platform for them. Until the launch of the database, their cultural self-expressions had tended to lack recognition from the networks of publishers, critics, museums, libraries, and the institutional framework that authorizes, enables, empowers and sustains cultural and artistic practice, as posited by the lineage of theorists associated with Pierre Bourdieu.

The database contains three major independent blocks that allow for mutual illumination and complementarity: (a) the self-expressions of the sem-terra in the formative years of the MST (1984-2003) across several media: children's drawings and compositions, choreography, murals, paintings, films, photography, sculptures, theatre, essays, music, lyrics and poetry; (b) "About the landless" includes expressions by renowned intellectuals and artists; (c) a

4 The initial three-year project was developed at the University of Nottingham, which first housed the bilingual database The Sights and Voices of Dispossession: The Fight for the Land and the Emerging Culture of the MST (The Movement of the Landless Rural Workers of Brazil/ As imagens e as Vozes da Despossessão: A Luta pela Terra e a Cultura Emergente do MST. It is now developed and housed by Queen Mary University of London and it is commonly referred to as the Landless Voices/Vozes Sem Terra database. 
third block provides reference material, including: academic work, bibliography, a glossary and cartography/tables of landlessness and of the social movementenabled settlements.

Underlying the database is an important articulation of cultural theories, mainly by one of the most renowned Brazilian theorists in Pedagogy and Social Science, Paulo Freire, as well as Russian semiotics of culture. Of particular interest were insights from the method that Freire developed during his career to enable a culture to speak for itself and thus move away from the well-known form of oppression that is the denial of voice and expression to the other (FREIRE, 1998, p. 120). Validating and empowering a culture through its own discourses and ideas was in fact a major concern for him (HADDADIN, 2003). The collection of resources was thus oriented towards the sem-terra/Sem Terra themselves who provided the themes that evoked and created their cultural universe, not as objects of research, but as subjects of their thinking. The Freire-inspired framework further implied that editorial interventions would be kept to a minimum, especially the a priori limiting of number and types of resources. This view of culture, which makes the landless protagonists of their own history, gave rise to the first block that makes up the main bulk of the database.

But culture is also made up of interacting semiotic systems. Freire's wordbased network of associations for the creation of a cultural universe was then extended so as to absorb other media. Relevant insights thus came particularly from the Leningrad school of Russian semiotics of culture that found its way to Tel Aviv. Itamar Even-Zohar developed an equally relational and functional view of culture as a polysystem to highlight a dynamic system made up of multiple and interdependent sub-systems. A polysystem is a network of simultaneous relations among sub-systems; the value that each one takes on is relative to the function of the other (EVEN-ZOHAR, 1979, p. 290). The merging of these mutually complementary theoretical frameworks enabled the project to feature culture as the networking of a plurality of media having the sem-terra/Sem Terra not as objects, but as the subjects of various expressions.

A polysystem also projects beyond itself and interacts with other polysystems. The culture of the MST, which in fact is not an island by itself, interacts with other segments. Networks of solidarity and knowledge production beyond the sem-terra's/Sem Terra's cultural universe were also then included. The second major block of the database, "About the landless", thus projects statements by renowned Brazilian artists and intellectuals who share their accumulated cultural knowledge and social capital with the sem-terra/Sem Terra: Frei Betto, Sebastião Salgado (who also donated several of his highly-priced photographs to the database), Chico Buarque, Haroldo de Campos, Antonio Candido, Oscar Niemeyer and Tetê Moraes who speak with the sem-terra in expressions of solidarity and 
empower the sem-terra from outside their own circle. It is noteworthy that the database houses a historical recording of Freire's last public statement before his death in May 1997, as the mentor of the educational project of the MST, in which he talks of the task of education within the context of the sem-terra, as an exercise in citizenship and re-insertion into history ${ }^{5}$.

The decision to use a web-enabled database was multi-layered. The web open-ended accommodation of resources across several media would project the sem-terra/Sem Terra's wide range of cultural expressions and particularly its oral and visual works with a completeness unimaginable in a traditional print format. The page-bound format of books is also limited in showing semiotic systems and cultures working by association. The hypertext, that links several texts, in turn, has enabled the presentation of the sem-terra culture as a complex network of several interacting media. Moreover, the Procrustean use of technology default alphabetical arrangement of resources or of existing categories, such as those used in library cataloguing systems, would in their generality obscure important aspects of the sem-terra/Sem Terra culture and crystallize it according to a pre-defined model that would alienate them. Freire has warned against this "cultural invasion", a term he uses when people are approached as objects rather than subjects and their culture is nullified or reduced to silence. This, of course, runs counter to the project's aim of giving voice to and validating the culture of the sem-terra/Sem Terra. The research thus developed an in-depth analysis of their own artefacts to elicit the categories provided by the material itself. The most productive categories immediately stood out, namely: "Rehabilitation of Traditions and Country Culture" and "Icons, Symbols and Monuments".

\section{Speculative research on the potential pedagogical impact of the database}

Responses to Schwendler's invitation for prospective teachers attending her module on Pedagogic Work at UFPR to visit and assess the database con-

5 "I send a message to young teachers [...]: live for me, now that I cannot live myself, with children and with adults who, in their struggle, seek to be themselves, men and women [...] Education is one of the keys to open [...] doors. I never forgot that lovely phrase which I heard from an educator, a peasant literacy worker from a group of Sem Terra in an enormous settlement in the state of Rio Grande do Sul where I once was, when he said: 'by the strength of our work, through our struggle, we cut through the barbed wire of the latifundium and we entered it, but when we got there, we saw that there were other barbed wires, like that of our ignorance. Then I understood even better, on that day', he said, 'that the more innocent we are, the better we are for the world's owners'. [...] I find that it is a task that is not only political, not only ideological, but also pedagogical. Without this there can be no Agrarian Reform" (VIEIRA, 2003). 
firmed the contribution intended by its conception (full statements are available upon request). Their particularly illuminating assessment of the achievements of the database is summed up below.

Conceptual impact was by far the trainees' most prominent response. An overriding majority of trainee teachers ( 43 out of 44 ) mentioned that they had little if any previous knowledge about the movement and its culture and stressed the importance of the new knowledge provided by what they view as an innovative and wide-reaching database. Its rare, original focus on the selfproduction of a historically marginalized social segment offers several angles for the understanding of landlessness across ages, generations, genders and educational levels, and also of the way society acts towards the sem-terra/Sem Terra. It also enables an in-depth knowledge of a social movement, of the way it uses art to construct history and a collective identity and to keep alive ideals of justice in land distribution. Interaction with the resources was for them a shock into the reality and specificity of a culture strongly marked by a trajectory of struggle, achievements and losses.

New conceptual knowledge is inextricably bound up with a cultural/ attitudinal change in relation to social movements, more specifically to the MST. In fact, 22 respondents indicated a change of attitude and a revision of their previous misconceptions and misjudgements of the sem-terra/Sem Terra derived from the media's dissemination of defamatory readings of the landless movement, which are, in turn, reproduced by society at large. It is the duty of prospective educators to pass on to future generations a different view from the "(mis)-education" provided by a deceitful and prejudiced media, namely that the MST is a partisan flag raised from time to time, without a collective engagement and an identity - an organization made up of trouble-makers, rebels and frightening loafers who take over land that does not belong to them or wage class war for its own sake. Some felt humbled by the sem-terra's/Sem Terra's political consciousness, its strength for struggle, its collective organization and values of solidarity; others regretted having absorbed the media's negative projections that stigmatized them. Trainees who happen to come from a background of latifundium owners realized they had been long alienated. Access to the cultural self-expression of the landless further opened the way for informed critical thinking and productive debates, while shedding hasty impressions that overlooked the complexity of landlessness and of the struggle for land.

Another 21 respondents stressed the importance of the database's incorporation of contributions from renowned intellectuals that revealed that the struggle of the sem-terra is theoretically informed. Noteworthy are the references to the mentor of the educational programme of the social movement, Paulo Freire: his illuminating statements create a link with the trainees' previous knowledge 
that his pedagogy relates to social transformation, humanization and liberation; he also brings to the Movement the value of emancipation from the condition of being oppressed towards the conquest of their historically denied rights to quality education.

The integrity of those artists who also engaged in dialogue with the Movement - Chico Buarque, Sebastião Salgado and Oscar Niemeyer - aroused sympathy and solidarity for those who struggle for land. Their expressions, which may be seen as a counter-statement to the media's, legitimize the Movement in its positive aspects, provide a more human and non-judgemental look at the sem-terra: their needs, fears, insecurities, anguish and ideals. Two trainees, however, also mentioned the aporias of cultural legitimizing: on the one hand, it is tactical (in that it arouses motivation and interest in the sem-terra/Sem Terra) which is only temporarily valid, because, ideally, a social segment would not need the power of an individual to give it positive visibility. But, significantly, the database does not reflect a power hierarchy and the artefacts of the sem-terra/ Sem Terra are given marked prominence.

Trainees envisaged pedagogical and professional trajectory redirections through the newly-learned Cultural Studies approach, that is, instrumental impact. Some were particularly impressed by the fact that the research for the database was a United Kingdom initiative, which implies that the legitimization of the landless culture was taking place outside Brazil. For them, the bilingual configuration of the database enables the sharing of the experience of one of the world's major social movements. They think that the wealth of knowledge enabled by the database is of utmost importance for educators to learn about the cultural production and the history of the MST, the largest social movement in Latin America, and about a culture different from theirs, as processes of alterity are essential for education to fulfil its transformative role.

The attention of a cohort of 11 respondents was particularly drawn to the sem-terra's/Sem Terra's struggle for education and the Movement's emancipatory and liberating pedagogical project in the encampments and settlements, of which they were not aware ${ }^{6}$. The project legitimizes the culture of the land/country. They foresee that this research initiative may lead to changes in educational policies in Brazil, what may be categorized as instrumental impact. Ultimately, the database, in the view of some, is an excellent tool for educators to propose a broader project of economic, social and political transformation of the country.

6 It is noteworthy that on December 11, 1995, the MST awarded the "Education and Participation" Prize of UNICEF for its programme called For a public school of quality in the settlement areas, developed in several states. According to UNICEF, the MST programme for education "contributed to consistent instruction with the rural environment and the recovery of citizenship" (CALENDÁRIO Histórico dos Trabalhadores, 1999, p. 83). 
It is notable that another 11 respondents, astonished, "travelled through the pages with the children's drawings". The database enables trainees valuable foreknowledge, in preparation for their future career, that the landless children, from an early age, are politically aware of processes of exclusion from the unfair society in which they live, and struggle to change this oppressive reality with remarkable strength; that they critically represent their history through textual productions. The depth of their drawings also brings intense reflection on the marked intergenerational transmission of knowledge of and engagement in the struggle for land. They understand and already struggle for their ideals. The political awareness and ability to criticize of 9 or 10 year-old landless children are comparable to that of the adult trainees' today. The children's intense participation in the construction of history further contributes to the documentation of the Movement history.

The trainees confirm the operational hypothesis of the Landless Voices Project that the symbolic capital (Bourdieu) afforded by its dissemination of their sem-terra's/Sem Terra's self-expression dignifies and empowers these social actors. They expect the landless children to feel very happy and fulfilled by the recognition of their artefacts in the database.

\section{Case studies: the social and pedagogic impact of the database in four settlement schools in Brazil}

The aims and objectives of the exploratory visits to four schools in rural settlements, two in the State of Paraná and two in the State of São Paulo (see above), in late 2013, were the preliminary assessment, via workshops, of the reception of the web-enabled database by non-academic users and its achievements in expanding educational resources, preserving countryside traditions, transmitting the historical experience of struggle for land to a younger generation, and raising the profile of those whose identity has been historically shaped by an absence (landlessness) ${ }^{7}$. An enabling factor has been Brazil's attempts to combat the country's digital divide and to recognize, respect and disseminate, via the web, the various kinds of knowledge produced by all types of communities (SILVEIRA, 2001, p. 29).

7 The staff of the schools were present during the workshops. Permission for the workshops to be conducted had been obtained from parents and school directors in compliance with Queen Mary's Research Ethics requirements. 
In both states, there were groups of adolescent students and smaller children aged 7-10 years old. The two age groups will be analyzed separately. The schools visited will be seen to be in settlements which are landmarks in the history of the struggle for land and education in Brazil.

The Rural State School Iraci Salete Strozak is in the settlement Marcos Freire in Rio Bonito do Iguaçu, in mid-west Paraná, the region with the largest concentration of settlements in the state. The dawn of April 171996 marked the beginning of a two-year struggle of more than 3,000 families who occupied the latifundium Giacomet-Marodim. This was the largest encampment in Latin America. The expropriation of the 26,000 farm hectares took place in 1998, when 1,501 families were settled. Before the occupation, Rio Bonito do Iguaçu had little more than five thousand inhabitants; today that number has multiplied and the settlement has become one of the largest in Brazil. Approximately 2,500 students benefit from children's elementary, secondary, youth, adult, and special education (CAPITANI, 2011). This school is also the base for 9 itinerant schools serving 67 encampments in the area.

The Contestado settlement is located 70 kilometres from the capital of Paraná, Curitiba. On February 7, 1989, the Santa Amélia farm, which had hitherto belonged to the Incepa Group, a manufacturer of ceramics that had contracted debts with banks, was occupied by landless families, with the objective of taking over the land, producing and living on their production. In December 1991, 108 families were settled. The settlement has demonstrated its strength in the organization of education across all levels, from early childhood education to graduation. But it was only after 13 years of hard struggle that the eponymous state-run primary and secondary school was built. The school strives to ensure that children, young people and adults remain in the country and do not lose their roots. On August 27, 2005, the first Latin American School of Agro-Ecology (ELAA) was implemented in the settlement, an initiative of Via Campesina, with the support of the Paraná state government (CAPITANI, 2013).

The implementation of both schools in the state of Paraná was the result of the settled communities' struggle for schooling close to where learners live. The schools have strong ties with their communities and the Landless Workers Movement, particularly through its educational sector.

The São Bento and Che Guevara Schools are located in eponymous neighbouring settlements in Pontal do Paranapanema, in the state of São Paulo. Fernandes and Stedile have pointed out the historical importance of the area in terms of land conflict and territorialization of the landless: 
Pontal do Paranapanema is a region of southwest São Paulo, at the meeting of the Paraná and Paranapanema rivers, which was transformed into one of the main centres of land conflicts in the country because of more than one million hectares of public lands whose titles were falsified by landowners but that legally belonged to the government of the state of São Paulo. The origin of grilagem [falsifying of documents] goes back to the 1950 s, but it had its greatest occurrence - and the assurance of impunity - during the military dictatorship [1964-81]. Because of the pressures of the MST, the state of São Paulo began to follow suit for the reintegration of ownership against the landowners' fraud and settle the Sem Terra on the recovered farms (FERNANDES; STEDILE, 1999, p. 25).

Between 1994 and 2004, there were only classrooms in these settlements; educational provision was by teachers from the urban schools without a specific background in rural issues. After the establishment of the settlements, the state schools were created; these have a very good infrastructure, including technology, and quality education is provided by teachers who are better prepared for the reality of rural settlements. Most of the learners have access to technology also via their mobile phones. Some former learners from these schools are now students of the MA in Territorial Development of the São Paulo State University at Presidente Prudente.

\section{Adolescents}

In order to assess whether and how the database expands existing educational resources, these learners were asked to look at its cartography section and comment on the knowledge of their own culture enabled by these resources (including regional diversity). Examples of prompts on the use of resources of the database in pedagogical context included:

Does the Landless Voices site offer anything that you cannot find in your textbooks? The database shows the culture of the sem-terra/Sem Terra in other parts of Brazil; is it important for you, in the south of Brazil, to learn about the culture of other landless people in the Amazon area? 
All replies related to conceptual knowledge were highly positive. Learners read a lot into the human dimension in the cartography of landlessness and stressed that they found much more in the maps than in textbooks.

In order for the role of the database in the transmission of historical experience/cultural memory to be assessed, learners were prompted to look at the map of landlessness in Brazil in 1984 and to contrast and compare them to the map of the settlements in 2013 and to comment on what it reveals about their families' struggle. They realized that the map activity remarkably helps them to better visualize their families' struggle and the contribution of the movement to historical change. Students in Paraná responded enthusiastically to this topic, whereas those in São Paulo were more reticent about their Sem Terra legacy and their status as residents in the settlements.

Learners were also invited to listen to songs in the database by the artists of the Movement, intended to preserve country tradition. In particular, they were asked to comment on the song "For honour and for love", about the dilemma of a police officer in love with a landless woman in an encampment and his duty of evicting the landless. They liked the love dilemma in the lyrics. But the overwhelming majority wanted the database to also incorporate funk and other musical developments that are meaningful to their age group.

In order for symbolic capital (Bourdieu) to be rendered discernible, learners were also prompted to express their views on the dignifying/empowering impact of the dissemination of their culture's artefacts by a renowned institution abroad. Prompts included:

(a) Please look at the children's drawings. Is it a good idea to have the landless children's views presented to the world? Why?

(b) I am a university lecturer abroad. Students there who analyzed the landless children's drawings and compositions were impressed by their views. Is this important for you?

(c) What would you like to see added to the site?

Learners in the four schools in the two states acknowledged, in their own terms, the dignifying power of the database. They used their robust critical skills in assessing gaps in the resources and, with autonomy of thinking, provided their own perspective on what other items of knowledge are culturally relevant for them. These include:

(a) Recognition of the sem-terra/Sem Terra as a class via what is already uploaded on the database is indisputably valid in terms of the class being represented. However, they would like their own contribution 
to merit the same recognition. In other words: there are individuals within this class.

(b) Brazil's problems pointed out by the children and adolescents in the database are again indisputable. However, there are gaps. They would like to send their own contribution to the database, which would include the following items:

- The country's social inequalities, especially with reference to social services;

- Precarious transportation in the rural areas and particular problems of accessibility for children with special needs (students in Paraná were quite emphatic about this point, more specifically on the difficulty of disabled children to get to the distant rural schools using unpaved country roads);

- The ponderous bureaucracy and slow response to demands when one tries, for example, to start a small business (more prominent in the state of São Paulo);

- Bullying of, and prejudice (racial, social, economic) against, the sem-terra/Sem Terra;

- The gender-related suffering of those who are particularly discriminated against in the countryside, notably gays and women (rendered more explicit in the state of Paraná);

- The problem of pollution by the use of "slash and burn" agriculture agrotoxics, and absence of litter collection, which is then buried or burnt (rendered more emphatic in the state of São Paulo);

- With reference to cartography, they pointed out the need for the database to also include information on rural schools in the country, specifying those which provided internet access, food and quality transportation.

In consonance with their noteworthy autonomy of thinking, the learners themselves took the initiative of proposing the production of a booklet (drawings or texts, according to their aptitude) on the topics above for uploading on the database. Those in São Paulo, who had access to and practice with the internet, in demonstration of solidarity values, volunteered to work in pairs with those who lack it, to develop the theme of their preference from the breakdown above; they would particularly stress the problem of the large-scale sugarcane monoculture and its ecological consequences. 


\section{Children 7-10}

Younger children in the four settlements were invited to listen to the children's songs in the CD Growing a ring o'roses (VIEIRA, 2003). These lyrics were composed by the Movement's artists, particularly Zé Pinto, to cater for the specific nature of rural education and the transmission of the Movement's ideals of preservation of country traditions, transmission of historical experience and fostering of important values such as ecological balance (see VIEIRA, 2007b). Learners in the Marcos Freire settlement (Paraná) revealed a strong sense of history - they were very motivated and responded well to the lyrics, which connected them to their own experience; they were also preparing themselves for a school party celebrating the history of the Movement and were very glad to find the words to the anthems of the Movement in the database.

The response of the children in São Paulo's schools was quite distinctive. Children in the São Bento School revealed remarkable skills for their age in the assessment of what is culturally relevant for them and responded unfavourably to each of the lyrics whose apparently attractive titles they had chosen. In their view, the sound and the beat were fine but the singing voice was irritating and very thin. They also found that the words of the lyrics were better suited for pre-school children. They prefer, instead, the more interesting rap, "funk universitário" (younger people's funk developed mostly in Rio's favelas), and "funk sertanejo" (an approximation of Brazilian country music and the language and rhythms from Rio's favelas, directed towards the young). For them "Negro drama"/ "The drama of the blacks" is a good rap, because it has to do with social inequality between wealthy and poor people ${ }^{8}$. They also like other types of lyrics, for example, country music which their parents listen to and Bossa Nova lyrics by the composers João Bosco and Vinícius de Moraes. An important finding related to these children, who daily help their parents to milk cows to supply the nearby towns with dairy products, is that their musical preferences and sense of playfulness are traversed by peripheral urban references (e.g. "funk universitário"). Conversely, country music becomes increasingly popular in the major urban areas in the form of "funk sertanejo", as further evidence of

8 "Negro Drama", by the group called Racionais MC's, is a seven-minute rap to the sound of electronic keyboards. It thematizes the social theme of violence in everyday life towards darkskinned people in the urban periphery, a violence that is so impregnated in Brazilian culture that people find it normal for the poor and the blacks to die. It also has expressions of protest against the way the police acts towards these people. Its simple language acts like a weapon to raise the awareness of the marginalized (BONUGLI, 2012, p. 65-70). 
interaction between country and city. Questions raised for future research relate to the place for these younger children of country life/traditions and, in some cases, of the family's historical experience of struggle.

\section{Conclusion}

This article has analyzed the responses to landlessness-specific academic research within the framework of Cultural Studies by prospective teachers and non-academic users, namely, learners in rural settlement schools, and what effect it has on them. These preliminary assessments reveal a positive reception.

Conceptual, attitudinal and potential instrumental impacts are foremost in the case of prospective teachers. This paper concludes, however, on the need for impact assessment to also compare and contrast these speculative research findings to research on pedagogic impact with hands-on rural school teachers. The experience also points to the need for greater connectivity (liaison with other rural schools) to enhance the reach of the database to wider society. Ideally, sustained international collaborative research would enable a multiplying pedagogical impact through the involvement of other contributors from local institutions.

Workshops with learners in the rural schools have also revealed positive responses to the database. A distinction needs to be established, however, between positive responses to a punctual activity and impact, which hinges on sustained effort over time (MEAGHER, 2013). Pedagogical impact generation requires continuous interaction with learners.

The positive effect of cultural capital on these learners has been confirmed. However, in the specific context of settlements, there is a need for intergenerational difference and historical mutability to be embraced. For these young learners in the settlements, a successful struggle for land is a given and cultural empowerment that might also need to address their expectation of individual recognition. The adolescents also point to the need for materials production to be more participatory and to include their generation's agenda, or in Freire's terms, their own universe of discourse.

Areas of embarrassment in some learners' Sem Terra self-image have also been noted. It is important for the process of raising young learners' self-cultural image for landless-specific cultural knowledge to find its way into school syllabi and the training of teachers for rural areas and, in Schwendler's terms, for 
their social experience to be given visibility as legitimate historical knowledge (SCHWENDLER, 2010).

Recommendations for the social movement's educational project can also be elicited. The policy-makers and the artists of the MST, in their role as Gramscian organic intellectuals (BONES, 2003), would benefit from a greater awareness of generational differences and the fact that the cultural context of this younger cohort of learners is traversed by technology and the urban experience available to them via telecommunication. How to negotiate country tradition and the transmission of historical experience for this generation is a challenge that has been opened for policy-makers.

\section{REFERENCES}

BONES, Sávio. With hands calloused from poetry: the formation of organic intellectuals by the MST', in 'Studies, Statements and References' 2003. Available at: $<\mathrm{http}: / / \mathrm{www}$. landless-voices.org/vieira/archive-05.phtml? $\mathrm{rd}=$ WITHHAND546\&ng=e\&sc=3\&th=42 $\&$ se $=0$ > . Access: 31 Jan. 2015.

BONUGLI, Selma Regina. Oralidade, Poesia e performance em canções de rap como manifestação coletiva. Boiatá - Revista do GT de Literatura Oral e Popular da ANPOLL, n. 14, p. 63-81, ago./dez. 2012.

BOURDIEU, Pierre. Outline of a Theory of Practice. Translated by Richard Nice. Cambridge: Cambridge University Press, 1977.

BOURDIEU, Pierre. Distinctions. A Social Critique of the Judgment of Taste. Cambridge, MA: Harvard University Press, 1984.

CALENDÁRIO Histórico dos Trabalhadores. 3. ed. São Paulo: MST, Setor de Educação. 1999.

CAPITANI, Raquieli. Assentamento desenvolve economia do município de Rio Bonito. In: MOVIMENTO dos Trabalhadores Rurais Sem Terra MST. April, 21st, 2011. Available at: <http://www.mst.org.br/node/11623>. Access: 31 Jan. 2015.

CAPITANI, Raquieli. Assentamento Contestado desenvolve novo modelo de produção. In: MOVIMENTO dos Trabalhadores Rurais Sem Terra MST. April 2nd, 2013. Available at: $<$ http://www.mst.org.br/content/assentamento-contestado-desenvolve-novo-modelo-de-produ\%C3\%A7\%C3\%A3o>. Access: 31 Jan. 2015.

CHILDREN'S drawings. 2003. Available at: <http://www.landless-voices.org/vieira/ archive-04.phtml? sc $=1 \&$ ng $=\mathrm{e} \& \mathrm{se}=0 \&$ th $=11>$. 
EVEN-ZOHAR, Itamar. Polysystem Theory. Poetics Today, Tel Aviv, v.1, n.1/2, p. 287-310, 1979.

FERNANDES, Bernardo Mançano; STEDILE, João Pedro. Brava gente: a trajetória do MST e a luta pela terra no Brasil. São Paulo: Editora Fundação Perseu Abramo, 1999.

FREIRE, Paulo. Reading the word and the world. In: FREIRE, Ana M. Araújo; MADEDO, Donaldo (Eds). The Paulo Freire Reader. New York: Continuum, 1998, p. 163-185.

FREIRE, Paulo. Extension or Communication. New York: The Seabury Press, 1973.

GRAMSCI, Antonio. Cadernos de Cárcere. Volume 2. Caderno 12 - Apontamentos e Notas dispersas para um grupo de ensaios sobre a história dos intelectuais. Edição de Carlos Nelson Coutinho com Marco Aurélio Nogueira e Luiz Sérgio Henriques. Tradução de Carlos Nelson Coutinho. Rio de Janeiro: Civilização Brasileira, 2000.

GROWING a ring o'roses. (Vieira 2003). Available at: <http://www.landless-voices. org/vieira/archive-05.phtml? $\mathrm{rd}=\mathrm{GROWINGA246 \& ng}=\mathrm{e} \& \mathrm{sc}=1 \& \mathrm{th}=12 \& \mathrm{se}=0>$. Access: 31 Jan. 2015.

HADDADIN, Diala. Paulo Freire: A Brief De-Brief. Freire Online: A Journal of the Paulo Freire Institute/UCLA. v. 1, Issue 2, July 2003.

MEAGHER, Laura R. Research Impact on Practice: Case Study Analysis. Technology Development centre, Economic and Social research Centre, 2013. p. 33-35. Available at: <http://www.esrc.ac.uk/_images/Research-impact-on-practice_tcm8-25587.pdf>. Access: 31 Jan. 2015.

MULTIMEDIA Educational Resources for Learning and Online Teaching (MERLOT). Available at: <www.merlot.org>. Access: 15 Dec. 2007.

SCHWENDLER, Sônia F. Educação e movimentos sociais: uma reflexão a partir da Pedagogia do Oprimido. In: SCHWENDLER, Sonia F.; MIRANDA, Sônia G. (Eds.) Educação do campo em movimento: teoria e prática cotidiana. Curitiba: Ed. UFPR, 2010, v.1, p. 267-288.

SILVEIRA, Sérgio Amadeu. Exclusão digital: a miséria na era da informação. São Paulo: Editora da Fundação Perseu Aramo, 2001.

VIEIRA, Else R. P. The Sights and Voices of Dispossession: The Fight for the Land and the Emerging Culture of the MST (The Movement of the Landless Rural Workers of Brazil: As imagens e as Vozes da Despossessão: A Luta pela Terra e a Cultura Emergente do MST. 2003. Available at: <http://www.landless-voices.org/vieira>. Access: 31 Jan. 2015.

VIEIRA, Else R. P. Enhancing Cultural Studies through the Web Mode of Organization and Publication of Archives'. International Journal of Technology, Knowledge and Society, 2007a, p. 115-27.

VIEIRA, Else R. P. Music, Poetry and the Politicization of the Landless Identity. In: VIEIRA, Else R. P.; McGUIRK, Bernard (Eds.). Landless Voices in Song and Poetry. The 
VIEIRA, E. R. P. The Landless Voices Database: A Trajectory from Cultural Studies...

Movimento dos Sem Terra of Brazil (Anthology). Compiled and annotated by Else R. P. Vieira. Translated by Bernard McGuirk. Nottingham: CCC Press, 2007b. 243 p. ISBN: 978-1-905510-03-0 (UK); 978-1-60271-009-2 (USA). Pp xxviii-li (24 p.).

Texto recebido em 13 de fevereiro de 2015. Texto aprovado em 05 de março de 2015. 